\title{
'A HYPNOTIC VIEWING EXPERIENCE'. PROMOTIONAL FEATURES IN THE LANGUAGE OF EXHIBITION PRESS ANNOUNCEMENTS
}

\author{
Cecilia Lazzeretti and Marina Bondi
}

\begin{abstract}
Museums have become fully active cultural agents, pursuing educational aims but also trying to attract the largest number of visitors. Exhibition press announcements (EPAs) issued by museums reflect this tendency and address journalists as if they were 'customers' in a very competitive market. Building on Bhatia's work on promotional genres $(1993,2004)$ and recent corpus-based studies devoted to press releases (Catenaccio 2008; Lindholm 2008; McLaren and Gurâu 2005), this paper investigates lexicogrammatical forms typical of EPAs with the aim to demonstrate that they carry a strong promotional intent and reflect the value-system of the professional communities involved, i.e. art journalists and museum professionals. The study was carried out on a corpus of contemporary Anglo-American EPAs and shows the recurrent use of linguistic features that express positive evaluation of the exhibition, especially with regard to the semantic areas of novelty, quality, extensiveness and exclusiveness. Emotional linguistic features are also used in order to create 'news value' and excite curiosity around the artists and their artworks.
\end{abstract}

Keywords: Exhibition press announcements; Press releases; Museum public relations; Promotional genres; Evaluative language.

\section{Introduction}

This paper is concerned with a professional genre, exhibition press announcements (EPAs). These are to be considered as a sub-genre of the press release, much in the same way as Bhatia (1993: 74-75) views sales letters and letters of application as subgenres of a promotional letter genre.

EPAs belong to the series of press materials periodically issued by a museum's press office, which range from announcements of seasonal programs - i.e. texts which summarize the principal events scheduled in the year - to single exhibition announcements, devoted to one display in particular; from ordinary news about the museum or gallery such as announcements of artist talks, presentations of films or books, accomplishments, awards, new appointments, philanthropic events to crisis responses released in order to protect the image of the institution.

In our analysis attention is placed especially on EPAs as they appear particularly interesting in terms of linguistic choices and communicative strategies. Our aim is to 
explore the promotional features of the genre and to identify the relevant semantic categories with their typical phraseology.

As pointed out by Bhatia (2004: 133), "a positive description and evaluation of the product, service or idea being promoted" are typical of promotional genres. The concept of evaluation is therefore crucial for the scope of this paper. Our own analysis draws on relevant studies of evaluative language (Hunston and Thompson 2000; Hunston 2011) and looks in particular at the value dimension, i.e. expressions of the writer's opinion, reflecting the value system of the writer and the community (Hunston and Thompson 2000: 6). While acknowledging that evaluations of value are often highly implicit and that "solidarity is built between writer and reader precisely by not making explicit the evaluative significance of certain parts of the text" (Hunston 2000: 199), we aim to investigate the role of evaluative lexis and phraseology in establishing the shared values and value hierarchies that lie behind specific social practices.

EPAs allow members of the art professional community to communicate with each other and with the wider public of art lovers. Like other professional genres, they are "intimately linked to a discipline's methodology, and they package information in ways that conform to a discipline's norms, values and ideology" (Berkenkotter and Huckin 1995). As pointed out by Hunston (2011: 12) "evaluation construes an ideology that is shared by writer and reader", as "it takes place within a social and ideological framework". Evaluative phraseology in EPAs can be seen therefore as typically reflecting the value-system of two professional communities, in this case art journalists and museum professionals.

Several corpus studies have been conducted on press releases as a genre (among them, Catenaccio 2008; Jacobs 1999a; Lassen 2006; Lindholm 2008; McLaren-Gurau 2005; McLaren-Hankin 2008; Pander Maat 2007, 2008) but, as far as we could discover, the specific range of EPAs has been ignored and a corpus-based study on them has never been carried out. Furthermore, although promotional discourse has already been put in relation to press releases (Bhatia 2004: 90; Catenaccio 2008; Erjavec 2004, 2005; Pander Maat 2007, 2008), the lexico-semantics of promotional discourse in EPAs has never been investigated.

This study will explore EPAs using corpus linguistics methods and combining them with qualitative analysis of the semantic and pragmatic features of the text. The analysis will focus on lexico-grammatical features, with special emphasis on the language of evaluation and on lexical strategies functional to promotional purposes.

The present article begins by providing general information on the genre of press releases and the sub-genre of EPAs, reviewing previous studies in these and related fields (sections 2 and 3). Section 4 outlines the design of the corpus, as well as the methods applied in the analysis. In sections 5 and 6 the results of the analyses are presented. The findings are summarized and conclusions are drawn in section 7 .

\section{Exhibition press announcements vs. press releases}

Drawing on the perspective of 'professional discourse' (Bazerman and Paradis 1991; Gunnarsson, Linell and Nordberg 1997), which tends to be related to specific professional settings, press releases should be put in relation both to media discourse, 
associated with the professional community of journalists, and promotional discourse, associated with the marketing and advertising environment.

Studies on media discourse focus mainly on the role of the news media and their messages, paying detailed attention to the structures and the strategies of such discourses and to the ways these relate to institutional arrangements, on the one hand, and to the audience, on the other hand (Fowler 1991; van Dijk 1988a, 1988b, 1995). As pointed out by Bell, "a large proportion of news which appears to be produced by local reporters is primarily the work of press officers working for companies, government departments or other organizations". (Bell 1991: 17). Press releases can be seen, therefore, as a preliminary phase in the process of news making and are worth analyzing in order to understand how they influence the final message of the media.

From the point of view of professional discourse, the informational function can be seen in conflict with the promotional function, which is also present in press releases: Jacobs draws attention in particular to the 'unpaid publicity' that press releases seem to convey, keeping a middle ground between advertising and news reporting (Jacobs 1999a: 307), while Bhatia (2004) points out that although "designed to serve informative purposes, ... (press releases) invariably focus only on positive aspects and incorporate persuasive and sometimes even promotional elements" (Bhatia 2004: 90). As a matter of fact, the mixing of promotional and informative features characterizes press releases since their first origin (Catenaccio 2008: 11). 'Promotional elements' do not necessarily harm subsequent news report and may even reinforce the press release itself: As suggested by Pander Maat, "strong positive statements can make the release look more newsworthy, and some journalists may think that a positive tone attracts readers. ... thus, promotional press releases may well succeed in generating free publicity" (Pander Maat 2007: 63).

Press release analysts tend to explore individual specific fields, as can be seen in the studies of Lindholm (2008), on European Commission press releases, and McLarenGurau (2005), on press releases issued by UK biotechnology companies. Nonetheless, the attention paid to EPAs has been very limited, to the point that they can be considered a fairly unexplored field. Attention has been paid to other textual genres belonging to the visual arts environment, such as museum labels, wall texts, catalogue entries, brochure descriptions (Ravelli 2006) and exhibition presentations in museum websites (Bondi 2009; Corbella 2008). The latter can be considered very similar to EPAs and are often derived from them. Bondi, in particular, highlights the promotional nature of exhibition web-presentations through the language of evaluation, contributing to the positive image of the artist, the curator and the museum itself (Bondi 2009: 127).

EPAs may be comprised under the wide definition of "texts in museums" (Ravelli 2006: 2): Written explanatory texts and descriptions, which have become crucial for cultural institutions in terms of communication with their audiences. Ravelli (2006: 3) relates the growing need for extended texts to the development of thematic exhibitions with high educational goals aiming to attract a wide range of visitors, starting from the 1940s onwards (McManus 2000). She also places emphasis on the language of exhibition texts, pointing out that the communicative success of an exhibition is mostly a matter of professional skill: "Visitors are frustrated by texts which are overly complex" (2006: 4). And indeed EPAs writers, with their own ability, may contribute crucially to the overall success of exhibitions, from raising the media profile 
and managing their relationships with stakeholders, to attracting new audiences and regular attendees.

Little scholarly research addresses specifically museum public relations (see in particular Adams 1983; McLean 1997; Schoen 2005; Gürel and Kavak 2010): Its main focus is on the importance of public relations, media editorials and word of mouth for this environment, especially since museums started to depend on their public for patronage and support, due to shrinking sources of income. An abundance of tips on how to promote exhibitions may also be accessed at non-academic sources, such as museum professionals websites and journals ${ }^{1}$. Expert advice usually includes the need to "keep paragraphs short" and "make sure that the language is simple, factual, but lively" (Braithwaite 2004). Museums PRs also say that art journalists seem to be attracted by "interesting angles", such as "objects not seen by the public before", "new research or a recent discovery", "relevance to something topical being widely discussed", "a human interest story" (Calder 2008).

In this paper we argue that the language of EPAs is influenced by a twofold aim: On the one hand, they have to arouse journalists' interest in order to gain a positive press coverage; on the other, they have to attract the largest number of visitors and serve as marketing tools for museums. The audience of EPAs is also twofold, as they reach directly the media community and potentially, through online publication (see section 3 ), the general public. Reflection of these two opposing professional demands is the massive use of evaluative language addressing the value systems of journalists and museum professionals at the same time.

\section{The e-dimension of exhibition press announcements}

A key issue that needs to be explored when addressing the textual genre of EPAs is their e-dimension, i.e. their online publication.

Press releases compete for attention with hundreds of others each day not only within journalists' crowded mail inboxes, which are still their principal destination, but also on the web, where they are increasingly being placed. The availability of press releases on websites is particularly appreciated by media people, who can access online press materials selectively, wherever and whenever they need them, without even calling the press officer. Thus, when published on websites, press releases may completely bypass journalistic intervention and address the public directly, serving as direct marketing tools (Catenaccio 2008; Strobbe and Jacobs 2005). Considering this scenario, online EPAs can reach marketing aims by providing potential visitors with useful information, encouraging advance booking, or boosting e-commerce and merchandising. There is so much potential in spreading on line EPAs that nowadays many companies provide services of direct e-mailing of text and image press releases to databases of art professionals as well as lay people. ${ }^{2}$

\footnotetext{
${ }^{1}$ See, for instance, Museums Journal and Museum Practice, online publications of the UK's Museums Association, that can be accessed by members at www.museumsassociation.org

${ }^{2}$ A significant example of this kind of service in the field of art is the international network $e$ flux (www.e-flux.com), reaching more than 50.000 visual art professionals on a daily basis through its
} 
Once the gatekeeping role traditionally played by journalists in handling paper press releases is bypassed, press release writers feel no longer constrained by rules and conventions. It comes as no surprise, therefore, that e-releases are characterized by a more promotional tone in comparison with traditional press releases (Strobbe and Jacobs 2005) and show explicitly their hybrid nature, partly informative and partly promotional. Although placed in specific press areas within museum websites and therefore apparently still reserved to a well defined professional category - journalists EPAs have been turned into public documents and internet is rapidly changing their use and language.

But how do journalists react to these changes and to the massive use of promotional language in press releases determined by online publication? Although press releases in general are openly disregarded by journalists, who often complain that they are badly written or too enthusiastic and self-celebratory, previous studies carried out in this field show that media people actually depend on the "information subsidies" provided by press releases (Gandy 1982: 61), as they cannot cover all newsworthy events in person. This turns out to be true for art journalists too, who necessarily rely on EPAs when writing about an exhibition they did not manage to visit. A golden rule should be that you cannot review an exhibition before seeing it with your own eyes; nonetheless, many critics base their journalistic evaluation on press materials and interviews previously arranged, often as a consequence of their busy agenda or their physical distance from the exhibiting venue. Promotional language may therefore survive in their subsequent coverage, generating "free publicity" (Pander Maat 2007: 63). There is also evidence that "promotional language is dealt with differently in different sectors of the press" and that "special interest media are apparently quite willing to recycle promotional elements" (Pander Maat 2007: 93). Probably art magazines and newspapers art sections belong to these categories sharing a more tolerant approach towards promotionally dressed up press releases, but in order to make claims in this sense a thorough ethnography-based process analysis would be needed. As suggested by Catenaccio, Cotter, De Smedt et al. (2011: 1848) "detailed empirical evidence for the journalistic use of source media" - the "news transmutation process" could be explored with the help of current technology, "by tracking electronically and/or ethnographically shifts and changes in the text as it develops (locally and globally) towards its final version for publication or presentation".

Adopting the ethnographical perspective, the analysis of EPAs could also profit from studies on art exhibitions reviews, as they represent a second phase in the life of EPAs and can determine their value and their effectiveness. Interesting studies have been published in the field of art exhibitions reviews, such as Swales (2004b) and Radighieri (2005, 2009). This particular aspect, however, is beyond the scope of this paper.

website, e-mail list and special projects. Its news digest - e-flux announcements - distributes information on contemporary art exhibitions, publications and symposia all around the world. 


\section{Corpus and methods}

\subsection{Corpus}

The corpus of materials collected for this paper includes 120 EPAs (more than 150.000 words) accessed at museums websites: One half of them comes from London museums and the other half from museums based in the United States (mostly in New York), as listed below.

\begin{tabular}{|l|l|l|l|}
\hline & Institutions & Location & EPAs \\
\hline 1 & The Frick Collection & New York & 10 \\
\hline 2 & Metropolitan Museum of Art & New York & 10 \\
\hline 3 & Museum of Modern Art & New York & 10 \\
\hline 4 & National Gallery & London & 10 \\
\hline 5 & National Gallery of Art & Washington & 10 \\
\hline 6 & National Portrait Gallery & London & 10 \\
\hline 7 & Royal Academy of Arts & London & 10 \\
\hline 8 & Solomon R. Guggenheim Museum & New York & 10 \\
\hline 9 & Tate Britain & London & 10 \\
\hline 10 & Tate Modern & London & 10 \\
\hline 11 & Victoria and Albert Museum & London & 10 \\
\hline 12 & Whitney Museum of American Art & New York & 10 \\
\hline
\end{tabular}

Table n. 1. List of the institutions accounted in compiling the EPA corpus

Covering a period comprised between February 2008 and May 2009, the corpus presents a large variety of historical currents and artists, from ancient Roman art up to contemporary art. EPAs collected in the corpus were issued by both non profit institutions, such as the London National Gallery, and private foundations, such as the Solomon R. Guggenheim Foundation.

The following table summarizes the features of the corpus:

\begin{tabular}{|l|r|}
\hline EPA corpus \\
\hline Corpus size & $<150.000$ \\
\hline Number of texts & 120 \\
\hline Full texts & Full texts \\
\hline Medium & Written (press releases) \\
\hline Subject & $\begin{array}{r}\text { Exhibition press } \\
\text { announcements }\end{array}$ \\
\hline Authorship & $\begin{array}{r}\text { Acknowledged experts } \\
\hline \text { Language }\end{array}$ \\
\hline Publication date & Texts written in English \\
& by native speakers \\
\hline
\end{tabular}

Table n.2. Features of EPA corpus 
With regard to the authorship of the texts, it has to be noticed that EPAs cannot usually be ascribed to a single writer, but preferably to a composite team of experts. Although $80 \%$ of the texts collected in the corpus are "signed" by professional press officers specialized in arts and related fields, who provide their names and contact information at the end of the sheet, the final version of the press release is more often the result of several inputs coming from different sources. The first draft, for instance, can be traced back to a text written by the curator of the exhibition, who first conceived the project and wrote it down in order to present it to the reference institution; the text is often revised by members of the managerial staff - i.e. the director of the museum, the board of directors, etc. - , while other useful comments and suggestions may come from co-workers, before the final draft is released.

\subsection{Methods}

As suggested for example by Stubbs $(1996,2001)$, the present analysis combines a quantitative or statistical approach with a qualitative and analytical one. The corpusbased approach seems to be particularly insightful in analyzing specific lexicogrammatical choices of press releases, although, when looking at evaluative expressions or at the use of linguistic means of emotional appeal, qualitative analysis becomes essential. Evaluation is often expressed in a cumulative and implicit way; moreover, no set of grammatical or lexical forms can entirely encompass the range of expressions of evaluation. Thus, following Hunston (2011: 4), it may be assumed that "evaluative language is more suited to text-based than to corpus-based enquiry".

The data processing consisted of different stages, ranging from computer-based to manual analysis of the texts. At the initial stage, the documents were saved in .pdf format (graphic version), then they were saved as .txt and sanitized in order to make them accessible for computer programs. Texts were processed through WordSmith Tools 4.0 (Scott 2004) and TextSTAT 2.8.c (Hüning 2001-2002).

Following Hunston 2002, the EPA corpus was explored in terms of frequency, phraseology and collocation of items. The analysis moved from the single lexical element to words in combination, patterns and elements of a local grammar of evaluation (Hunston and Sinclair 2000; Hunston 2011: 119-150). Corpus evidence of promotional features was collected bearing in mind Römer's (2008: 126) claim that evaluative lexis cannot be identified with quantitative methods alone and her choice to move "from an automatic computer-based to a mainly manual but in part computerassisted [...] type of analysis".

The top twenty nouns and the top twenty adjectives in the corpus were identified and analyzed in comparison with a reference general corpus, the BNC corpus $^{3}$. A similar comparative analysis was carried out regarding the collocates of the most frequent noun in the corpus, exhibition, within a span of four words on either side of the node.

In consideration of the statistical relevance of positive adjectives, underlined by the comparison between the EPA corpus and the BNC corpus, special attention was

\footnotetext{
${ }^{3}$ The BNC has been accessed via BNCWeb at http://bncweb.lancs.ac.uk
} 
paid to evaluative linguistic features - adjectives, adverbs and lexical phrases, - which were grouped into specific semantic categories. These categories arose from qualitative analysis of the data: They are, thus, ad hoc categories, potentially identifying the valuesystem instantiated in the genre of EPAs.

An overview of less frequent lexical items also revealed the presence of emotionally charged words which can be specifically related to the notion of newsworthiness (Bell 1991). The analysis centred on items that could be attributed to the semantic dimension of affect "concerned with registering positive and negative feelings" identified by Martin and White (2005: 42) in their framework for mapping attitude in English texts. Of the three semantic regions identified by Martin and White (2005) - emotion, ethics and aesthetics - aesthetics dominated the most frequent lexical items attributed to the exhibition, but affect seemed to play a central role in characterizing elements of the exhibition.

The functional value of emotional linguistic features in the EPA corpus can be explored drawing on the work by Janoschka 2004 in the field of advertising, by pointing out that particular vocabulary, such as powerful 'trigger words', is "a means of persuasion which appeals to users emotionally" (Janoschka 2004: 151). Professional copywriters also compile and share listings of 'trigger words' (Yadin 1994) and know how to use them to get the reaction they want: For instance, to subconsciously spark a feeling of well-being and urge to buy in a reader.

The narrative potential of EPAs was also explored bearing in mind the analysis carried out by Toolan (1988) on the basic components of the narrative - events, setting and character - and looking for markers of affect that were felt to play a role in highlighting the news story potential of EPAs, and therefore likely elements of narrative of complication, instability, suspense or resolution.

\section{Results of the analysis: Most frequent semantic categories}

The frequency list ${ }^{4}$ highlights - quite predictably - that exhibition, art and museum the three most frequent nouns in the EPA corpus - can be considered as key features. Overwhelming is the use of adjectives that express positive evaluation, as shown in table n. 3, presenting the top 20 adjectives in the corpus in order of decreasing frequency, and n.4, listing the top 20 adjectives collocating with exhibition also in order of decreasing frequency.

new, national, public, American, modern, other, free, contemporary, royal, early, major, important, available, late, British, private, great, original, general, significant

Table n.3. Top 20 adjectives in the EPA corpus

\footnotetext{
${ }^{5}$ Word frequency information regarding the EPA corpus was based on raw frequency. The BNC was explored considering only the written section of the corpus and ranking was based on normalized frequency, e.g. per million words.
} 
possible, new, major, special, national, solo, comprehensive, royal, original, small, British, monographic, modern, large, final, contemporary, chronological, available, unique, public

Table n.4. Top 20 adjectives collocating with exhibition in the EPA corpus (span: min. 0/max. 4 words)

The tendency to associate positive collocates with the word exhibition can be identified in the BNC corpus as well (see table n.5 below, presenting the top 20 adjectives collocating with exhibition in the BNC corpus), but seems to be more evident in the specialized corpus, especially with regard to features of novelty, quality and comprehensiveness: Adjectives such as original, comprehensive and unique appear only in the EPA top 20 collocates.

new, major, national, great, international, annual, recent, royal, current, British, open, Scottish, contemporary, ideal, important, large, permanent, special, small, other

Table n.5. Top 20 adjectives collocating with exhibition in the BNC corpus (span: min. 0/max. 4 words)

Among the other collocates missing from the BNC corpus top 20, solo, monographic and chronological can be ascribed to the technical vocabulary of EPAs. Available and possible in reference to exhibition are also typical of EPAs, as they are functional, respectively, to highlighting additional services beside the exhibition (such as available catalogues, audio guides, gifts, images to download) and to introducing the mention of sponsors, as shown by the recurrent lexical sequence the is/was made possible by (40 occurrences in the corpus), where the slot can be filled with exhibition, catalogue, programme, and other similar expressions.

The analysis extended from evaluative adjectives to adverbs and lexical phrases carrying more or less explicit positive meanings in the EPA corpus. These were grouped into four main semantic fields, as shown in table n. 6:

\begin{tabular}{|l|l|l|}
\hline Semantic category & Linguistic features & $\begin{array}{l}\text { Total } \\
\text { occurrences }\end{array}$ \\
\hline Novelty & $\begin{array}{l}\text { new, original, rare, never been- VERBpp-before, rarely } \\
\text { been -VERBpp, first, for the first time }\end{array}$ & $\mathbf{6 2 6}$ \\
\hline $\begin{array}{l}\text { Quality and } \\
\text { importance }\end{array}$ & $\begin{array}{l}\text { major, } \text { important, significant, } \text { outstanding, remarkable, } \\
\text { masterpiece/-s, landmark }\end{array}$ & $\mathbf{4 4 7}$ \\
\hline $\begin{array}{l}\text { Extensiveness and } \\
\text { quantity }\end{array}$ & $\begin{array}{l}\text { comprehensive/-ly, extensive/-ly, more (than) + numerals, } \\
\text { over + numerals, large/-st }\end{array}$ & $\mathbf{2 2 0}$ \\
\hline $\begin{array}{l}\text { Specialty and } \\
\text { exclusiveness }\end{array}$ & $\begin{array}{l}\text { site specific, special, especially, unique, exceptional/-ly, } \\
\text { exclusive/-ly }\end{array}$ & $\mathbf{1 6 8}$ \\
\hline
\end{tabular}

Table n.6 - Most frequent semantic categories and related linguistic features in the EPA corpus 
Each of these semantic categories - namely novelty, quality and importance, extensiveness and quantity, specialty and exclusiveness - will be dealt with in turn in the next subsections, providing illustrating examples.

\subsection{Novelty}

Novelty is the most significant semantic category in the EPA corpus, both from a qualitative and a quantitative perspective. The aspect of 'novelty', in fact, is crucial in order to make an exhibition appealing and to attract audiences. When deciding to visit and review an art show, a journalist expects to see something original, which has never been on view before, or, at least, not in the most recent years. As a consequence, the adjective new plays a significant role in the specialized corpus: It is the most frequent adjective in the entire corpus and the second most frequent adjective collocating with exhibition after possible. It is often used as an attributive adjective of the nouns exhibition/s, galler-y/ies, display/s and work/s (66 total occurrences). It may be even reinforced by other positive adjectives, such as major, important, original, as shown in example (1).

(1) This new and important Hammershoi exhibition at the Royal Academy is therefore most timely [...]. (Royal Academy of Arts, London. Vilhelm Hammersh $\phi i$ : the Poetry of Silence, 28 June - 7 September 2008)

Also in the BNC corpus the co-occurrence of new with exhibition is relevant: The adjective ranks $1^{\text {st }}$ among the collocates, with a mutual information score of 1.7.

On the other hand, the adjective original as a collocate of exhibition is a peculiar feature of the EPA corpus and ranks only $100^{\text {th }}$ in the BNC.

(2) Frank Lloyd Wright: From Within Outward, an original exhibition which examines Wright's concepts of space [...]. (Solomon R. Guggenheim Museum, New York. Frank Lloyd Wright: From Within Outward. May 15 - August 23, 2008)

The idea of novelty is often expressed phraseologically, giving evidence to the fact that the exhibition shows works never been exhibited before or rarely exhibited. Two patterns - never been - VERBpp - before and rarely - VERBpp - appear in the EPA corpus, providing respectively 21 and 23 occurrences. With regard to never beenVERBPp -before, the variants never-before-seen, never been shown, never been exhibited, never been displayed, never before been on public view, has never been an exhibition, never before been seen have also to be taken into account. Considering the phrase rarely- VERBpp, the slot can be filled by expressions such as seen/exhibited/shown/on view/available.

(3) "There has never been an exhibition like this before [...]". (Victoria \& Albert Museum, London. Maharaja: The Splendour of India's Royal Courts. 10 October 2009 - 17 January 2010) 
In order to be successful, an exhibition has to offer something new, something original or even never been seen before, and preferably something which is on display for the public for the first time. In the EPA corpus the numeral first appears 319 times and in 64 cases as modifier of the noun time. It can also modify the noun exhibition (53 examples), in order to underline that the exhibition itself is the first in its own genre, as shown in example (4).

(4) $[\ldots]$ this will be the first exhibition to look at Turner's work [...]. (Tate Britain, London. Turner and the Masters. 23 September 2009 - 31 January 2010)

First is already one of the most frequent collocates of exhibition in the BNC corpus, with a mutual information score of 1.7.

The lexical phrase for the first time is the most frequent four-word cluster in the entire corpus (50 occurrences). Possible further combinations are on display for the first time (five occurrences), on show/on view/shown for the first time (five total occurrences) and together for the first time (10 occurrences). The latter is used in order to signal that a group of artworks has been reunited especially for the occasion of the exhibition.

(5) [...] more than 200 original Frank Lloyd Wright drawings, many of which are on view to the public for the first time [...]. (Solomon R. Guggenheim Museum, New York. Frank Lloyd Wright: From Within Outward. May 15 August 23, 2008)

The notion of novelty fits very well the value system of both art experts obviously sensitive to innovation and originality and art journalists, also looking for news value.

\subsection{Quality and importance}

The second most frequent type of evaluation is an evaluation of importance. The peculiarity of the type of evaluation has been highlighted by Thompson and Hunston (2000: 24) as one of the parameters of evaluation, somehow distinct from the good-bad, positive-negative parameter that may characterize many other values. Evaluations of importance highlight elements rather qualifying them as inherently good or bad. If novelty is in itself assumed as a value within the genre (on the assumption that exhibitions must be based on a new idea), importance is attached to the exhibition, to the art object or to its features as a way of attracting the reader's attention to it and constructing a hierarchy of elements rather than of values.

In order to reassure the press - and, indirectly, the audiences - not only about the quantity of works on display but also about the quality of the exhibition, the pieces on view are qualified as important (116 occurrences in the EPA corpus), significant (68 occurrences), outstanding (19), remarkable (36), or even masterpieces (68 occurrences). In order to highlight its importance, the exhibition may also be defined as a landmark 
one (19 occurrences). The following examples - from (6) to (7) - illustrate the use of evaluative adjectives in the semantic field of quality and importance.

(6) This is one of the most important gifts in the history of Tate and these outstanding works will enhance many different areas of the Tate Collection. (National Gallery, London. The Simon Sainsbury Bequest. 8 July - 5 October 2008)

(7) Dan Graham [...] is the subject of a landmark retrospective [...]. (Whitney Museum of American Art, New York. Dan Graham: Beyond. June 25 - October 11, 2009)

Among positive adjectives, major plays a relevant role in the EPA corpus. Even if other adjectives show a more consistent presence in the texts, major, in fact, is one of the most frequent (125 instances) with a meaning in context which is definitely positive, whereas adjectives such as national (328 instances), American (237) and modern (224) can be considered as neutral. The BNC gives major as a relevant collocate of exhibition, ranking $2^{\text {nd }}$ after new, with a mutual information score of 3.5. Major hence appears as the most typical attribute when referring to an art exhibition. In 23 instances provided by the EPA corpus major appears as attributive adjective of exhibition, as shown in example (8).

(8) Jenny Holzer [...] is the subject of a major exhibition [...]. (Whitney Museum of American Art, New York. Jenny Holzer: Protect, Protect. March 12-May 31, 2009)

Major is also used as a modifier of works (8 instances), retrospective (4), survey (3), collections (2), loans (2). Even single occurrences testify the use of this adjective as a means for describing something in the context of the exhibition, or more often the exhibition itself as 'more important, serious, or significant than other things' (from the Collins Cobuild English Language Dictionary).

The comparative dimension is of course implicit in the expression of importance, even if the reasons for the importance and the values that justify the attribution of importance may remain unstated.

\subsection{Extensiveness and quantity}

The third most frequent semantic area in our corpus points to the notion of 'extensiveness' as a key point in the value system of art discourse. Novelty is not enough: It is also important to be able to cover the field significantly and present a wide range of works of art. While being creative and convincing, the exhibition announcement has to be honest, never deceptive. One of the most frequent complaints about art exhibitions derives, in fact, from the disappointment caused by a poor selection of works, often concealed by a very aggressive communication campaign, which sets high expectations on audiences. In order to prevent criticism of this kind, 
EPAs have to give assurance of the quantity of the works on display. Therefore the selection privileges linguistic features indicating abundance and extensiveness.

Adjectives like comprehensive (25 occurrences) and extensive (23 occurrences) are peculiar to the EPA corpus, as they do not appear among the first 100 adjectives collocating with exhibition in the BNC. They may be referring not only to the exhibition itself, but also to the catalogue which accompanies the exhibition, as shown in the following examples.

(9) "The Americans" is the most comprehensive and in-depth exploration of Frank's original book ever undertaken. (National Gallery of Art, Washington. Looking In: Robert Frank's "The Americans". January 18 through April 26, 2009)

(10) The exhibition is accompanied by a comprehensive catalogue tracing [...]. (National Gallery, London. Renaissance Faces: Van Eyck to Titian. 15 October 2008 - 18 January 2009)

Quantity adverbs like more (than) (27 occurrences) and over followed by numerals (30 occurrences) also play a significant role. The quantity of works on display is often undetermined and the authors of EPAs may prefer to talk about 'many' works rather than quantify them exactly; nevertheless the language insists on the idea of abundance as an essential ingredient for the success of the exhibition.

(11) The exhibition will include more than 130 exhibits [...]. (Tate Britain, London. Van Dyck in Britain. 18 February - 17 May 2009)

The use of a superlative like largest in reference to exhibition or similar expressions (33 occurrences) works in the same direction, i.e. it gives assurance of the quantity of the works on view.

(12) Radical Light is the largest show of its kind [...]. (National Gallery of Art, Washington. Radical Light: Italy's Divisionist Painters 1891-1910. 18 June - 7 September 2008)

\subsection{Specialty and exclusiveness}

A further semantic category identified in the EPA corpus is the one of specialty and exclusiveness. Expressions belonging to this category tend to underline the 'sitespecific' idea, which is a useful means for exclusivity: When an installation is sitespecific - i.e. meant and created for a particular space or for a particular art project, which also inspired it - visitors have the unique opportunity to admire works in their original context and, hopefully, to better understand them. Hence the evidence in EPAs to the expression site-specific (18 occurrences). 
(13)

Philippe Parreno [...] will install a site-specific, illuminated movie marquee [...]. (Solomon R. Guggenheim Museum, New York. Theanyspacewhatever. October 24, 2008 - January 7, 2009)

The adjective special also plays a significant role in the EPA corpus, with 16 occurrences of the collocation special exhibition. Similarly, the BNC corpus puts the adjective special between the 20 most frequent collocates of exhibition, ranked $18^{\text {th }}$ with a mutual information score of 2.0. It turns out that an exhibition has to be a special event, held in special sites, featuring works especially made for the occasion (78 total occurrences of the adjective and the adverb in EPA).

(14) On the occasion of the Frick's special exhibition of Old Master paintings [...]. (The Frick Collection, New York. Masterpieces of European Painting from the Norton Simon Museum. February 10 - May 10, 2009)

(15) [...] a new work created especially for the Guggenheim's rotunda. (Solomon R. Guggenheim Museum, New York. The Third Mind: American Artists Contemplate Asia, 1860-1989. January 30 - April 19, 2009)

Speaking of exclusiveness, the adjective exclusive and the adverb exclusively have also to be taken into account: The EPA corpus contains 13 occurrences of both forms, mostly referring to the exhibition and its content.

(16) Andrea Riccio: Renaissance Master of Bronze will be shown exclusively at The Frick Collection. (The Frick Collection, New York. Andrea Riccio: Renaissance Master of Bronze, October 15 - January 18, 2009)

The different aspects underlined so far - novelty and originality of the exhibition design, intrinsic importance of the elements, extensive coverage, rarity of the displayed works and specific criteria of selection of works and spaces - work together to make the exhibition an exclusive event which cannot be other than unique (42 occurrences) or exceptional (17 occurrences), as shown in the following example:

(17) $[\ldots]$, bringing together for the first time a unique visual record [...]. (National Portrait Gallery, London. Wyndham Lewis Portraits. 3 July-19 October 2008)

\section{Less frequent semantic categories}

An in-depth reading of all the texts featured by the EPA corpus revealed the presence of other, less frequent, linguistic items that can be traced back to the aim of "creating the news', as they carry a strong emotional connotation and are therefore used to dramatise the situation and to create a case around an artist and his work.

Discussing the evaluative semantics of journalistic discourse, White (2006) identifies the presence of "attitudinal 'provocations' - formulations where the author's 
subjective presence is clearly made salient in some way, with this subjectivity capable of being seen as directing the reader towards a particular attitudinal assessment" (2006: 9). Martin and White (2005: 64-66) mention in particular the use of lexical metaphors and non-core vocabulary, but also simple intensification as a means for provoking an attitudinal response in readers.

According to Bell (1991: 100), "Journalists do not write articles. They write stories". The emotional linguistic features identified in EPAs recall the idea of discovery, mystery, opposition, success, provoking the readers' attention and interest: They are functional to a story - a journalist's most wanted item - and create therefore 'news value'. Press officers can 'create the news' and move the interest of the readers giving particular evidence, for instance, to the most captivating details of the biography of the artist, or telling a story about a single work on view. Journalists seek stories that are exciting, controversial and novel; EPAs writers have to provide them in order to pursue a media coverage.

30 different emotional expressions - mostly adjectives and nouns - belonging to four main semantic categories (see table n.7) were identified by manual scanning of the corpus, totalling 180 instances over 120 EPAs: In average terms, it means that each announcement contains 1,5 of them. Although the occurrences were not relevant in terms of overall frequency, it appeared worth comprising them in the analysis.

\begin{tabular}{|l|l|l|}
\hline $\begin{array}{l}\text { Emotional semantic } \\
\text { categories }\end{array}$ & Linguistic features & $\begin{array}{l}\text { Total } \\
\text { occurrences }\end{array}$ \\
\hline $\begin{array}{l}\text { Discovery and } \\
\text { mystery }\end{array}$ & $\begin{array}{l}\text { discover-y, reveal, revel-ation/-atory, myster-y/-ious, } \\
\text { hypnotic, enigmatic, intriguing }\end{array}$ & $\mathbf{8 6}$ \\
\hline $\begin{array}{l}\text { Irregularity and } \\
\text { opposition }\end{array}$ & $\begin{array}{l}\text { controvers-y/-ial, provocat-eur/-ive, outrage/-ous, } \\
\text { scandal/-ous, challenge, adversity }\end{array}$ & $\mathbf{4 0}$ \\
\hline Success & talent/-ed, genius, myth, legendary, triumph & $\mathbf{3 2}$ \\
\hline Energy & vibrant/-ly, groundbreaking & $\mathbf{2 2}$ \\
\hline
\end{tabular}

Table n.7 - Emotional semantic categories and related linguistic features in the EPA corpus

Each semantic category identified by emotional words will be dealt with in turn. The group of items expressing discovery and mystery appears to be the most important, quantitatively speaking, throughout the EPA corpus, in establishing the narrative element of the news story. The subject of the exhibitions and the artists may be presented as enigmatic, mysterious or hypnotic, suggesting to the readers that there is something fascinating to discover or to reveal within the topic featured by the exhibitions, like a hidden treasure or a secret, as in examples (18) and (19).

(18) Jan Lievens (1607-1674), one of the greatest yet most enigmatic Dutch painters [...]. (National Gallery of Art, Washington. Jan Lievens: A Dutch Master Rediscovered, October 26, 2008- January 11, 2008) 
(19) Gordon's 24 hour psycho back and forth and to and fro, 2008, which will be shown in its entirety [...], creating a hypnotic viewing experience. (Solomon R. Guggenheim Museum, New York. Theanyspacewhatever. October 24, 2008 - January 7, 2009)

What has to be explored can be the obscure biography of an artist or the genesis of a single art work on display. Expressions related to the semantic field of discovery and mystery may also highlight the scientific value of the exhibition when they refer to preliminary studies and research carried out by the curators in order to unveil hidden aspects in the biography and the work of the featured artist in forms of narrative suspense.

Concordance analysis shows how emotional words highlighting mystery in the narrative often combine with other expressions of the general idea of quality of the exhibition. The adjective mysterious, for instance, may appear with positive collocates, such as beautiful, fresh, urgent, ornate or in the co-text of words like masterpiece, creating powerful combinations, as in the following example:

(20) The work that inspired this exhibition is small, ornate, mysterious, and beautiful [...]. (The Frick Collection, New York. Andrea Riccio: Renaissance Master of Bronze, October 15 - January 18, 2009)

The second most frequent emotional semantic category - 'irregularity and opposition' - can contribute both to the narrative sections, by highlighting complications, and to the argumentative sections, presenting critical views on the exhibition/artist/work of art. One of the most obvious markers is the word family controvers $-y /$-ial. The following excerpt (21) is taken from the announcement of an exhibition on the American painter James Whistler. artist James Abbott McNeill Whistler (1834-1903). (The Frick Collection, New York. Portraits, Pastels, Prints: Whistler in The Frick Collection, June 2 August 23, 2009)

The adjective controversial is used here in order to introduce the figure of the artist and to excite curiosity around him since the very first lines of the text. It is also used in combination with a second adjective (colorful and once controversial), which further reinforces the idea of controversy as a point of interest for readers. Something controversial can stimulate discussion, comments, opposite viewpoints and is therefore a great starter for a journalistic review.

Other expressions belonging to the semantic fields of irregularity and success challenge, outrag/eous, provocat-eur/-ive, revolution-ary - work in the same direction and add colour to the story by creating an atmosphere of potential narrative complication. It comes as no surprise, therefore, that they concentrate in the central paragraphs of the announcement, where a narrative purpose is more evident, or even in the main title of the press release, which is its most evident part, as in example (22). 
(22) Francis Bacon's Provocative Works [...]. (Metropolitan Museum, New York. Francis Bacon: a Centenary Retrospective. May 20, 2009 - August 16, 2009)

A similar role can be played by adjectives referring to the success of the artist, somehow constructing the value of the artist or work of art on the vast consensus obtained and suggesting the structure of a success story. The emphasis created for example by an adjective like legendary in (23) qualifies the identity of the characters before they are introduced.

(23) SERIAL LANDSCAPE PHOTOGRAPHS BY THREE LEGENDARY AMERICAN PHOTOGRAPHERS ON VIEW AT NATIONAL GALLERY OF ART OCTOBER 12, 2008-MARCH 15, 2009 Washington, DC - Three important and beautiful series of black-and-white landscape photographs will be showcased in, Oceans, Rivers, and Skies: Ansel Adams, Robert Adams, and Alfred Stieglitz, on view from October 12, 2008 through March 15, 2009. (National Gallery of Art, Washington. Oceans, Rivers and Skies: Ansel Adams, Robert Adams, and Alfred Stieglitz, October 12, 2008- March 15, 2009)

Significantly, in this case the title omits the name of the three famous photographers featured by the exhibition (Ansel Adams, Robert Adams and Alfred Stieglitz), as the adjective legendary alone serves to catch the attention, while guiding the reader toward the names specified in the opening paragraph.

At other times legendary can be functional to the narration of the biography of the artist, marking a crucial phase in their career or giving specific evidence to a particular work, as in example (24).

(24) Annie Leibovitz [...] began working for Vanity Fair, and then Vogue, creating a legendary body of work. (National Portrait Gallery, London. Annie Leibovitz: a Photographer's Life. October 16, 2008 - February 1, 2009)

Emotional words of 'success' such as genius and talent also prove to be very powerful, especially when speaking of an artist. The strength of the evaluation leaves the reader little space for mild disagreement. The expressions can be even reinforced when used in the superlative form (the most talented) or in combination with positive adjectives (extraordinary, remarkable, prodigious, unique), as shown in example (25).

(25) [...] she has influenced multiple generations of artists with her unique and ever-evolving talent [...] (Solomon R. Guggenheim Museum, New York. Louise Bourgeois. June 27 - September 2008).

The last semantic category identified by emotional words in the EPA corpus is the one of energy. When describing the artworks on display, the writer may highlight one in particular by defining it as vibrant. The Oxford English Dictionary explains the meaning of this adjective as 'full of energy or enthusiasm, bold and strong; quivering, 
pulsating'. The word comes from the classical Latin verb vibro, which means 'to cause to vibrate, move rapidly to and from; to shake, quiver, vibrate'. This suggests energy, activity, alertness. In the EPA corpus the adjective vibrant modifies nouns referring to artworks or particular subjects depicted by artists. Expressions such as these help represent artworks as living things.

(26) "[... many of the images are today as breathtakingly vibrant and beautiful as they were centuries ago". (National Gallery of Art, Washington. Rare Manuscript Illuminations, March 1 - August, 2, 2008)

Applying Martin and White's (2005) framework for mapping attitude to the analysis of EPA corpus, it can be concluded that while the most frequent evaluative items characterize the event of the exhibition itself and can be therefore associated with the evaluative field of aesthetics (appreciation), the less frequent evaluative items deal with emotion (affect) and play a significant role in characterizing specific elements of the exhibition, such as the featured artists and the works of art on display.

Although functional to a story, the emotional linguistic features identified in the EPA corpus display a narrative potential which does not necessarily develop into a complete story structure comprising events, character and settings (Toolan 1998: 12). There would not be enough space for that in a single EPA, generally kept to one side of A4, or two at the most. It is up to the initiative of art journalists to make use of this potential in their articles and to elaborate a story around the narrative elements suggested, in nuсе, by EPAs.

\section{Conclusions}

The results of the analysis confirm that the promotional intent is very strong in EPAs and is directed not only to the principal recipient of the genre, i.e. art journalists, but, thank to their e-dimension, also to the general public. While captivating the attention of media people is necessary in order to guarantee press coverage of the exhibitions, attracting online audience can significantly increase the number of potential visitors. These communicative purposes are pursued through evaluative language identifying ad hoc semantic categories.

Quantitatively relevant in the corpus is the frequency of adjectives, nouns and phraseological units that express positive evaluation of the exhibition itself, as well as of the featured artists and the works on view. The analysis revealed the typical evaluative phraseology and recurrent lexical patterns characterizing the genre of EPAs: For instance, the adjective major, which appears as the most typical attribute of the noun exhibition and its synonyms, the adjective new - the most frequent between all the adjectives in the corpus - and patterns like never been -VERBpp - before (where the slot can be filled with expressions such as seen, exhibited, etc..) and for the first time (to be completed with on display, on view, etc..). Four semantic categories arose from this part of the analysis and were identified as characterizing the genre: Novelty, quality and importance, extensiveness and quantity, specialty and exclusiveness. 
It was also shown that EPAs writers often insert emotional linguistic features in order to dramatise the events and to create a case around an artist and his work by attributing them great 'news value'. Typical examples of these evaluative lexical items are adjectives as controversial, provocative, enigmatic, mysterious, nouns as talent, genius, verbs as discover, reveal. Although not equally relevant in quantitative terms, these expressions were analysed and classified as well into four ad hoc semantic categories: Discovery and mystery, irregularity and opposition, success, energy.

The examination of our corpus shows that the typical phraseology of EPAs does not only express the values considered crucial for professionals engaged in art exhibitions and for potential audiences - the novelty of the featured events, the quality, as well as the quantity of works on view, the exclusiveness of the occasion. The newsworthiness of the EPA itself has to be reinforced with specific powerful lexical patterns highlighting a different set of values, appreciated especially by journalists and art reviewers: The importance of discovering something yet unknown in the artistic field, the sense of mystery surrounding the artists or their works, the elements of irregularity and opposition characterizing artists' biographies, as well as their success in the art scene, the energy conveyed by the art works and the exhibition itself.

The semantic categories identified the value-system typical of the different professional communities involved in the genre of EPAs: On the one hand, the professionals in charge for the organization and the promotion of art exhibitions, such as curators, managers and press officers; on the other, media people interested in art news reports and reviews.

The results of the analysis on the language of EPAs can be useful for the professional community of art press officers, especially in terms of public relations education, as they allow learners and apprentices to become conscious of the typical features of the genre and of how they work. To be conscious of these features also means being able to use them appropriately, always remembering that a press release should be first of all informative and a clearly advertising tone should be avoided.

\section{Key to abbreviations}

BNC British National Corpus

EPA Exhibition Press Announcement

\section{References}

Adams, G.D. (1983) Museum public relations. Nashville: American Association for State and Local History. 
Bazerman, Charles, and James Paradis (eds.) (1991) Textual Dynamics of the Professions: Historical and Contemporary Studies of Writing in Professional Communities. Madison, Wi: University Of Wisconsin Press.

Bell, Allan (1991) The language of news media. London: Blackwell.

Berkenkotter, Carol, and Thomas N. Huckin (1995) Genre Knowledge in Disciplinary CommunicationCognition/ Culture / Power. Hillsdale, NJ: Lawrence Erlbaum.

Bhatia, Vijay Kumar (1993) Analysing Genre: Language Use in Professional Settings. London: Longman.

Bhatia, Vijay Kumar (2004) Worlds of Written Discourse: A Genre-Based View. London: Continuum.

Bondi, Marina (2009) Perspective and position in museum websites. In S. Radighieri, and P. Tucker (eds.), Point of View. Description and Evaluation across Discourses. Rome: Officina Edizioni, pp. 113127.

Braithwaite, Catherine (2004) How to work with journalists. Museum Practice 26: 44-47.

Calder, Penny Ritchie (2008) Promoting exhibitions to the press. Museum Practice 43: 60-61.

Catenaccio, Paola (2006) Looking beyond today's headlines: The Enron crisis from press release to media coverage. In M. Bondi, and J. Bamford (eds.), Managing Interaction in Professional Discourse. Intercultural and Interdiscoursal Perspectives, Roma: Officina Edizioni, pp. 159-172.

Catenaccio, Paola (2008) Press releases as a hybrid genre: Addressing the informative/promotional conundrum. Pragmatics 18.1: $9-31$.

Catenaccio, Paola, Colleen Cotter, Mark De Smedt et al. (2011) Towards a linguistics of news production. Journal of Pragmatics 43.7: 1843-1852.

Corbella, Silvia (2008) British and American museums promoting in-site events online: A museological and linguistic analysis. Unpublished Ma Thesis, University of Modena and Reggio Emilia.

Erjavec, Karmen (2004) Beyond advertising and journalism: Hybrid promotional news discourse. Discourse \& Society 15.5: 553-578.

Erjavec, Karmen (2005) Hybrid public relations news discourse. European Journal of Communication 20.2: $155-179$.

Fowler, Roger (1991) Language in the News: Discourse and Ideology in the Press. London/ New York: Routledge.

Gandy, Oscar H., Jr. (1982) Beyond agenda setting: Information subsidies and public policy. Norwood, NJ: Ablex.

Gunnarsson, Britt-Louise, Per Linell, and Bengt Nordberg (eds.) (1997) The Construction of Professional Discourse. London: Longman.

Gürel, Eda, and Bahtisen Kavak (2010) A conceptual model for public relations in museums. European Journal of Marketing 44.1/2: 42 - 65.

Hüning, Matthias (2001/2002) TextSTAT. Simple text analysis tool. Accessed at: < http://neon.niederlandistik.fu-berlin.de/static/textstat/TextSTAT-Doku-EN.html> 
Hunston, Susan (2000) Evaluation and the planes of discourse: Status and value in persuasive texts. In S. Hunston, and G. Thompson (eds.), Evaluation in Text: Authorial Stance and the Construction of Discourse. Oxford: Oxford University Press, pp. 176-207.

Hunston, Susan (2002) Corpora in applied linguistics. Cambridge: Cambridge University Press.

Hunston, Susan (2011) Corpus Approaches to Evaluation. London: Routledge.

Hunston, Susan, and John Sinclair (2000) A local grammar of evaluation. In S. Hunston, and G. Thompson (eds.), Evaluation in Text. Oxford: Oxford University Press, pp. 74-101.

Hunston, Susan, and Geoffrey Thompson (2000) Evaluation in Text. Oxford: Oxford University Press.

Jacobs, Geert (1999a) Preformulating the News. Amsterdam: Benjamins Publishing Company.

Jacobs, Geert (1999b) Self-reference in press releases. Journal of Pragmatics 31: 219-242.

Janoschka, Anja (2004) Web Advertising: New Forms of Communication on the Internet. Amsterdam: Benjamins Publishing Company.

Lassen, Inger (2006) Is the press release a genre? A study of form and content. Discourse Studies 8.4: 503-30.

Lindholm, Maria (2008) A community text pattern in the European Commission press release? A generic and genetic view. Pragmatics 18.1: $33-58$.

Martin, James R., and Peter R.R. White (2005) The Language of Evaluation. Appraisal in English. New York: Palgrave Macmillan.

McLaren, Yvonne, and Câlin Gurâu (2005) Characterising the genre of the corporate press release. Lsp and Professional Communication 5/1: 10-30.

McLaren-Hankin, Yvonne (2008) 'We expect to report on significant progress in our product pipeline in the coming here': Hedging forward-looking statements in corporate press releases. Discourse Studies 10.5: 635-654.

McLean, Fiona (1997) Marketing the Museum. London: Routledge.

McManus, Paulette (2000) Archaeological displays and the public: Museology and interpretation. London: Archetype Publications.

Pander Maat, Henk (2007) How promotional language in press releases is dealt with by journalists: Genre mixing or genre conflict? Journal Of Business Communication 44.1: 59-95.

Pander Maat, Henk (2008) Editing and genre conflict: How newspaper journalists clarify and neutralize press release copy. Pragmatics 18: 87-113.

Radighieri, Sara (2005) Arts in the news: Evaluative language use in the 'art review'. Proceedings from the Corpus Linguistic Conference Series 1. On line document accessed at $<$ http://www.Corpus.Bham.Ac.Uk/Pclc/>

Radighieri, Sara (2009) Spatial description in the art exhibition review: Reference as pointing and wandering. In S. Radighieri, and P. Tucker (eds.), Point of View. Description and Evaluation across Discourses. Rome: Officina Edizioni, pp. 97 -112. 
Ravelli, Louise J. (2006) Museum Texts: Communication Frameworks. London: Routledge.

Römer, Ute (2008) Identification impossible? A corpus approach to realisations of evaluative meaning in academic writing. Functions of Language 15.1: 115-130.

Schoen, Mary P. (2005) Museum-public relationships: Exploring the relationship management theory of public relations. Unpublished MA thesis, Louisiana State University, Baton Rouge, LA.

Scott, Mike (2004) Wordsmith Tools: Online Manual. Accessed at <http://www.lexically.net/Downloads/Version4/html/Index.html>.

Sinclair, John (1987) Collins Cobuild English Language Dictionary. London: Collins.

Strobbe, Ilse, and Geert Jacobs (2005) E-releases: A view from linguistic pragmatics. Public Relations Review 31: 289-291.

Stubbs, Michael (1996) Text And Corpus Analysis. Oxford: Blackwell.

Stubbs, Michael (2001) Words in culture 1: Case studies of cultural keywords. In M. Stubbs, Words and Phrases. Corpus Studies of Lexical Semantics. Oxford: Blackwell. pp. 145-169.

Swales, John (2004b) Evolution in the discourse of art criticism. The case of Thomas Eakins. In I. Bäklund, Maartala U. Melander, U. Börestam, and H. Näslund (eds.), Text I Arbere/Text At Work. Uppsala: Institutionen För Nordiska Sprak Vid Uppsala Universitet.

Thompson, Geoffrey, and Susan Hunston (2000) Evaluation: An Introduction. In S. Hunston, and G. Thompson (eds.), Evaluation in Text: Authorial Stance and the Construction of Discourse. Oxford: Oxford University Press, pp. 1-27.

Toolan, Michael J. (1988) Narrative. A critical linguistic introduction. London: Routledge.

Van Dijk, Teun A. (1988a) News as Discourse. Hillsdale, Nj: Erlbaum.

Van Dijk, Teun A. (1988b) News Analysis. Case Studies of International and National News in the Press. Hillsdale, Nj: Erlbaum.

Van Dijk, Teun A. (1995) Power and the news media. In D. Paletz (ed.), Political communication and action. Cresskill, Nj: Hampton Press, pp. 9-36.

White, Peter R.R. (2006) Evaluative semantics and ideological positioning in journalistic discourse. In I. Lassen (ed.), Image and Ideology in the Mass Media. Amsterdam/Philadelphia, John Benjamins Publishing Company, pp. 45- 73.

Yadin. Daniel (1994) Creative Marketing Communications. London: Kogan Page.

MARINA BONDI is Professor of English Language at the University of Modena and Reggio Emilia, Italy, where she is currently Dean of the Faculty of Letters and Philosophy. She has published on various aspects of discourse analysis and EAP, with particular reference to the argumentative features of academic discourse and to the role of metadiscourse and evaluative language. Her recent work centres on language variation across genres, disciplines and cultures through the analysis of small specialized corpora, with an emphasis on the humanities and social sciences. On language variation in specialized 
discourse she has published a number of articles and co-edited a number of volumes: Most recently, Academic Discourse across Disciplines with Ken Hyland, Managing Interaction in Professional Discourse: Intercultural and Interdiscoursal Perspectives with Julia Bamford, and Keyness in Texts with Mike Scott.

Address: University of Modena and Reggio Emilia, Department of Studies on Language, Text and Translation, Largo Sant'Eufemia, 19, I-41121 Modena, Italy. E-mail: Marina.bondi@unimore.it and www.lettere.unimore.it

CECILIA LAZZERETTI initially completed a Master's Degree in Classical Philology at Alma Mater University of Bologna, before turning her attention mainly to linguistics and communication studies. She received a second Master's degree in English Linguistics from the University of Modena and Reggio Emilia, where she currently does her doctoral work in the Department of studies on Language, Text and Translation, under the guidance of Professor Marina Bondi. As a free-lance journalist and press officer for a cultural institution engaged in exhibiting activities - Fondazione Cassa di risparmio di Modena - she is professionally involved in the media community. Her research interest concerns Corpus Linguistics, Discourse Analysis and Genre Studies, with a specific focus on art press releases.

Address: University of Modena and Reggio Emilia, Department of Studies on Language, Text and Translation, Largo Sant'Eufemia, 19, I-41121 Modena, Italy. E-mail: Cecilia.lazzeretti@unimore.it or www.lettere.unimore.it 